Current psychology letters

\title{
Psychological Influences on Yawning in Children
}

James R. Anderson and Pauline Meno

\section{(2) OpenEdition}

\section{Journals}

Electronic version

URL: http://journals.openedition.org/cpl/390

DOI: $10.4000 / \mathrm{cpl} .390$

ISSN: $1379-6100$

\section{Publisher}

Centre PsyCLÉ

\section{Electronic reference}

James R. Anderson and Pauline Meno, «Psychological Influences on Yawning in Children », Current psychology letters [Online], 11, Vol. 2, 2003 | 2003, Online since 30 March 2006, connection on 21

December 2020. URL : http://journals.openedition.org/cpl/390 ; DOI : https://doi.org/10.4000/cpl.390

This text was automatically generated on 21 December 2020.

(C) All rights reserved 


\title{
Psychological Influences on Yawning in Children
}

\author{
James R. Anderson and Pauline Meno
}

Introduction

1 Yawning occurs throughout the vertebrates, including fish, amphibians, reptiles, birds, and mammals (Baenninger, 1987). In humans, yawning is detectable in the foetus (de Vries, Visser, \& Prechtl, 1985; Sepulveda \& Mangiamarchi, 1995). The normal control of yawning is affected by brainstem lesions and other forms of neurological challenge (Barbizet 1958; D'Mello, Vincent, \& Lerner, 1988; Heusner, 1956). Adults yawn most frequently just before and after sleep and during tedious activities (Baenninger, Binkley, \& Baenninger, 1996; Provine \& Hamernick 1986; Provine, Hamernick, \& Curchak, 1987). Around 20 functions of yawning have been proposed (Smith, 1999), but there is little agreement about the major function of the behaviour. However, few would doubt that one of the most remarkable aspects of the behaviour in humans is its contagiousness. Just seeing, hearing, reading or even thinking about yawning can induce yawning, at least in adults (Baenninger \& Greco 1991; Provine, 1986; 1989a).

Given the widespread existence of yawning and its contagiousness, there is a surprising lack of studies on social influences on yawning in infancy and childhood, despite a call for research into the topic and its relevance to cognitive neuroscience (Provine 1989b). Piaget (1951) stated that yawning in response to seeing a yawn started in the second year of life, but in the half-century since Piaget's description there have been no systematic developmental studies of yawning and its influencing factors. In the present study we assessed the effectiveness of two stimuli known to elicit yawns in adults, namely a videotape showing frequent yawning and a narrative with frequent references to yawning, as yawn-eliciting stimuli in pre-school- and school-age children. MethodParticipants

3 Twenty-two children aged 34-53 months (Mean: 42 months) attending a University-run playgroup and 65 primary school children aged 5-11 years participated. The numbers of boys and girls participating were approximately equivalent, and sex was not considered as a factor in the analysis. 
Materials

4 Two "yawn stimulus" colour videotapes were made, one showing a close-range, face-on view of the head and shoulders of an adult male and a similar one showing an adult female. The adult talked about subjects of interest to pre-school children, including nursery rhymes and zoo animals, for 175 seconds, breaking off approximately every 10 seconds to yawn. Two similar control tapes were made in which the speaker smiled instead of yawning. In a pilot study these videotapes were shown to 16 individually tested adults who responded to a questionnaire about the extent to which each one made them either yawn or smile, or made them feel like yawning or smiling. Nine (56\%) of the adults yawned while watching or within 5 minutes of watching a yawn videotape, and another 3 adults (19\%) reported feeling like yawning. These results verified a previous finding and validated the videotapes as yawn-inducing stimuli (Provine 1986, 1989a). No smiling was induced by the smile videotapes.

Procedure

5 Each child was tested individually in a quiet room. Approximately half of the children in each age group viewed a yawn videotape first while the remainder saw a smile videotape first, with sex of the stimulus figure counterbalanced. Every child was thus exposed to 17 yawns and 17 smiles. To ensure that the pre-school children recognised yawning (or smiling) they were asked to clap their hands every time a yawn (or smile) appeared on the screen. The schoolchildren were simply asked to concentrate on what they saw as they would be asked about the film at the end. During video presentation the experimenter (PM) sat unobtrusively across the room and recorded any yawning or smiling by the child. Immediately after each videotape ended she asked whether the film made the child want to yawn, smile, or do nothing, with question order varied among the children. The child was then returned to the playroom or classroom where any occurrences of yawning or smiling in the ensuing 5 minutes were recorded.

All children were also individually exposed to two stories. The pre-school children were tested one week before the videotape condition. To control for a possible stimulus order effect, approximately half of the schoolchildren received the story 1-2 weeks before the videotape condition, the rest received it 1-2 weeks afterwards. The preschool children were told to pay attention to the stories as they would be asked which one they liked best; the schoolchildren were told they would be asked a question. The stories were adapted from two commercially available books for young children (Hargreaves, 1990a, b), and were selected to correspond to the videotape stimuli. In one of them, "Mr. Lazy" was described as yawning 10 times during the story and in the other "Mr. Happy" smiled 10 times. Approximately half the children in each age group received "Mr. Lazy" first and half received "Mr. Happy" first. Schoolchildren were given the choice between reading the stories or having the experimenter read them. When the experimenter read the stories she did not yawn or smile, and she noted any yawning or smiling by the child. After each story the child was asked whether it made them feel like yawning, smiling, or do nothing, with order varied among the children. The child was then returned to the playroom or classroom and monitored for yawning and smiling for 5 minutes.

Results

7 The results showed that none of the pre-school children yawned either during or after presentation of the yawn videotape, and none of them reported feeling like yawning. This is despite the fact that they all detected over $90 \%$ of the stimulus yawns, as 
indicated by their clapping responses. In contrast, between $12 \%$ and $60 \%$ of the schoolchildren in the different age groups yawned in response to the yawn videotape, rising to $22 \%$ and $70 \%$ when children who reported feeling like yawning without actually yawning were included. Pearson product moment correlations between age and proportion of schoolchildren yawning or feeling like yawning were positive and highly significant, $r=0.67$ and $r=0.87$, respectively, $p<.01$ (Figure 1,top). In both preschoolers and schoolchildren smiling was rare and unpredictable during videotape presentation and afterwards. There were no order effects and no effect of sex of the stimulus figure.
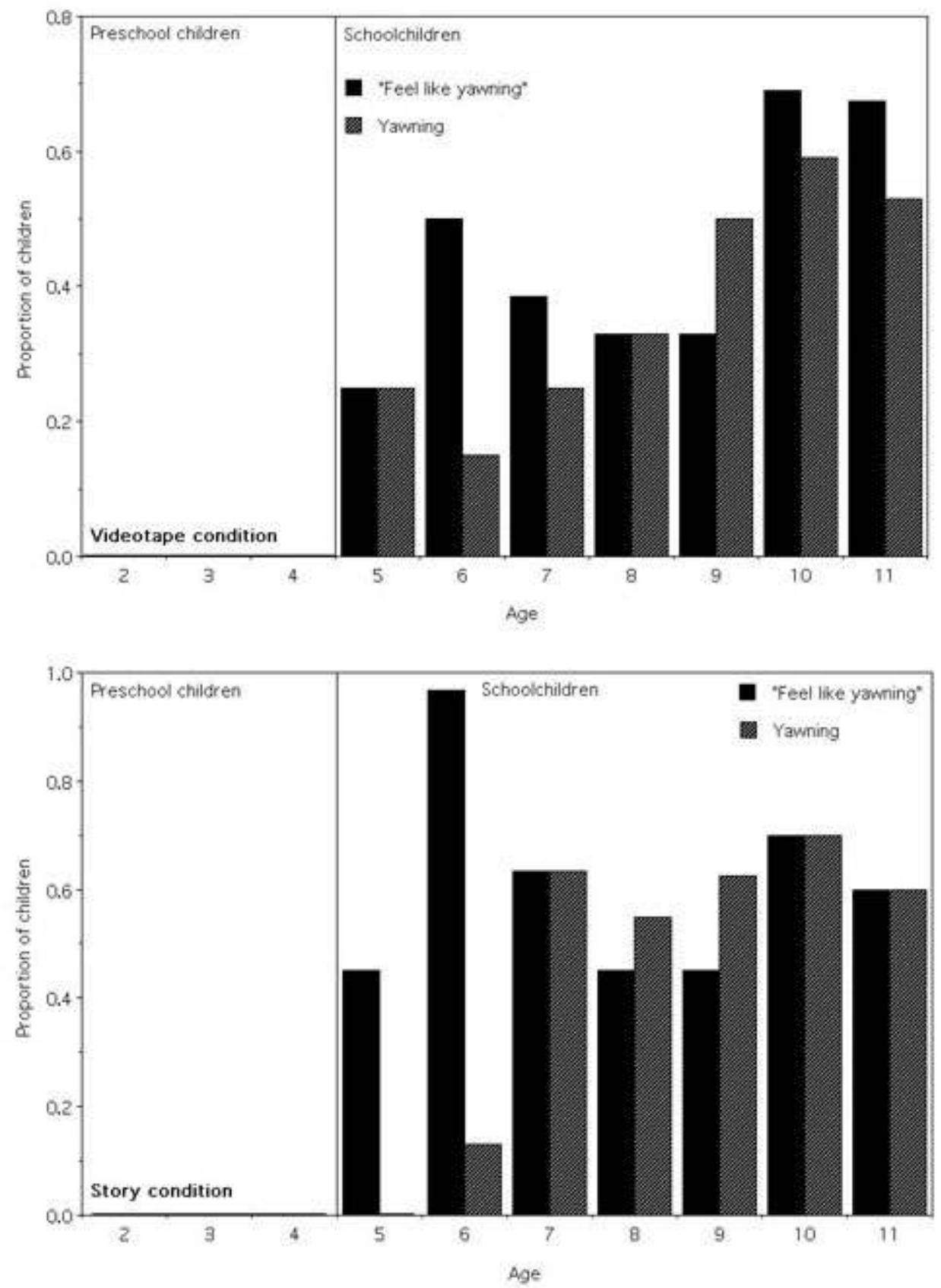

Figure 1.

Proportion of children of each age yawning or feeling like yawning in the videotape stimulus condition (top), and the story stimulus condition (bottom). 
containing 10 yawns had no influence on yawning or the desire to yawn in pre schoolers; neither occurred. Among the schoolchildren, no 5-year-olds yawned in response to the yawn story, but between $12.5 \%$ and $70 \%$ of older schoolchildren yawned either during or in the 5 minutes after exposure. Forty-four percent of 5-year-olds reported feeling like yawning, as did $44 \%-75 \%$ of the older schoolchildren. Correlation coefficients between yawn and desire to yawn and age were positive and highly significant for schoolchildren, $r=0.84$ and $r=0.86$, respectively, $p<.01$ (Figure 1, bottom). Yawning in one stimulus condition was related to yawning in the other: 20 of the 25 children who yawned in the videotape experiment also yawned to the story. The six youngest children to yawn (aged 6 or 7 years) were the only ones in their age-group who chose to read the story. Further, of the 31 children who yawned in the story condition, 29 (93\%) were rated blindly by teachers as being among the three most intellectually able pupils in their class, while 18 of 25 (72\%) children who yawned in the videotape condition were ranked in the top three.

\section{Discussion}

data strongly suggest that neither contagious nor story-induced yawning are reliable in children below the age of six years. In the videotape condition pre-schoolers but not schoolchildren were asked to clap each time they saw a yawn on the screen. However, it seems unlikely that this minor procedural difference underlies the agerelated trend observed, as a similar trend occurred in the story condition and no instruction to clap was given. The lack of psychological stimulus-induced yawning in younger school-age children contrasts with the high frequency of spontaneous yawning reported elsewhere in this age group (Koch, Montagner, \& Soussignan, 1987). Thus, whilst no doubt overlapping to some extent with spontaneous yawning in terms of underlying biological mechanisms (Gesell 1928), psychologically induced yawning requires additional explanation. Although Provine (1989b) emphasised the continuity between neonatal imitation of facial movements (Meltzoff \& Moore, 1977) and imitation of yawning, the lag between the two suggests slower development of mechanisms underlying imitative yawning, or even the involvement of different neuropsychological mechanisms.

The data obtained here also challenge Piaget's (1951) view that imitation of yawning becomes established in the second year. It is noteworthy that Piaget's observations were made on his own children; furthermore, model identity is known to affect the likelihood of neonatal imitation (Meltzoff \& Moore 1994). The influence of model familiarity on the likelihood of contagious yawning occuring in children has never been studied; to our knowledge it has never even been studied in adults.

11 It might be suggested that the increase in psychologically induced yawning in older children was due to an inhibitory effect of the observer, playgroup supervisor or teacher, as it is considered impolite to yawn in public. However, we know of know data showing such an inhibitory effect, and it could be argued that young children are in fact less likely than older children or adults to stifle yawns for reasons of etiquette.

12 So, what other factors might underlie the age-related trends reported here? Adults show individual differences in susceptibility to contagious yawning (e.g. Provine 1986, 1989b), but again the sources of the variability remain largely unstudied. Arousal, attention, personality and intelligence could all be influencing factors, and some of these may be implicated in the unanticipated finding that schoolchildren who were 
ranked highly in terms of intellectual ability and who chose to read the stories for themselves were especially likely to be influenced by the stimuli. The greater sensitivity to 'psychological' yawn stimuli might reflect enhanced self- and social awareness, related to reading ability (Garner 1987). A potentially fruitful line of investigation would be to assess socially induced yawning in relation to other aspects of early social-psychological development, such as empathy and theory of mind.

Acknowledgments

We thank the children, parents, and staff who made this work possible in the University of Stirling Psychology Department Playgroup and in Dunning Primary School. We also thank Ranald MacDonald for statistical advice and Bob Lavery for technical support. A fuller report is available upon request.

\section{BIBLIOGRAPHY}

Baenninger, R. (1987). Some comparative aspects of yawning in Betta splendens,

Homo sapiens, Panthera leo, and Papio sphinx. Journal of Comparative Psychology, 101, 349-354.

Baenninger, R., \& Greco, M. (1991). Some antecedents and consequences of yawning. Psychological Record, 41, 453-460.

Baenninger, R., Binkley, S., \& Baenninger, M. (1996). Field observations of yawning and activity in humans. Physiology and Behavior, 59, 421-425.

Barbizet, J. (1958). Yawning. Journal of Neurology, Neurosurgery and Psychiatry, 21, 203-209.

de Vries, J. J. P., Visser, G. H. A., \& Prechtl, H. F. R. (1985). The emergence of fetal behaviour. II. Quantitative aspects. Early Human Development, 12, 99-120.

D'Mello, D. A., Vincent, F. M., \& Lerner, M. P. (1988). Yawning as a complication of electroconvulsive therapy and concurrent neuroleptic withdrawal. Journal of Nervous and Mental Disease, 176, 188-189.

Garner, R. (1987). Metacognition and reading comprehension. Norwood, NJ: Ablex Publishing. Gesell, A. (1928). The mental growth of the pre-school child. New York: Macmillan.

Hargreaves, R. (1990a). Mr. Lazy. Handforth, UK:Egmont World.

Hargreaves, R. (1990b). Mr. Happy. Handforth, UK:Egmont World.

Heusner, A. P. (1946). Yawning and associated phenomena. Physiological Review, 26, 156-168.

Koch, P., Montagner, H., \& Soussignan, R. (1987). Variation of behavioral and physiological variables in children attending kindergarten and primary school. Chronobiology International, 4 , 525-535.

Meltzoff, A. N., \& Moore, M. K. (1977). Imitation of facial and manual gestures by human neonates, Science, 205, 217-219. 
Meltzoff, A. N., \& Moore, M. K. (1994). Imitation, memory, and the representation of persons. Infant Behavior and Development, 17, 83-99.

Piaget, J. (1951). Play, dreams and imitation in childhood. New York: Norton.

Provine, R. R. (1986). Yawning as a sterotyped action pattern and releasing stimulus. Ethology, 72, 109-122.

Provine, R. R. (1989a). Contagious yawning and infant imitation. Bulletin of the Psychonomic Society, 27, 125-126.

Provine, R. R. (1989b). Faces as releasers of contagious yawning: An approach to face detection using normal human subjects. Bulletin of the Psychonomic Society, 27, 211-214.

Provine, R. R., \& Hamernick, H. B. (1986). Yawning: Effects of stimulus interest. Bulletin of the Psychonomic Society, 24, 437-438.

Provine, R. R., Hamernik, H. B., \& Curchack, B. C. (1987). Yawning: Relation to sleeping and stretching in humans. Ethology, 76, 152-160.

Sepulveda, W., \& Mangiamarchi, M. (1995). Fetal yawning. Ultrasound in Obstetricsand Gynecology, 5, 57-59.

Smith, E. O. (1999). Yawning: An evolutionary perspective. Human Evolution, 14, 91-198.

\section{ABSTRACTS}

To trace development of contagious yawning, 87 children aged 2 to 11 years were tested in two putative yawn-inducing situations. Videotaped yawns did not induce yawning in children below 5 years. Reading or listening to a story about yawning had no effect before 6 years. After these ages, the probability of yawning in response to both types of stimuli increased progressively throughout childhood. Contagious yawning probably involves different mechanisms to those operating in neonatal imitation of mouth movements.

Afin d'évaluer le développement du bâillement par contagion, 87 enfants âgés de 2 à 11 ans ont été observés dans deux situations sensées induire le bâillement. Des bâillements présentés sur vidéo n'ont pas provoqué de bâillement chez les enfants de moins de 5 ans. Lire ou écouter une histoire à propos du bâillement n'a pas eu d'effet chez les enfants de moins de 6 ans. Chez les enfants plus âgés, la probabilité de bâiller en réponse aux deux types de stimuli a augmenté progressivement avec l'âge. Le bâillement par contagion impliquerait des mécanismes différents de ceux mis en jeu lors de l'imitation néonatale des mouvements de la bouche.

\section{INDEX}

Keywords: reading, yawning, imitation, pre-school, children, video 


\section{AUTHORS}

JAMES R. ANDERSON

Department of Psychology, University of Stirling Stirling FK9 4LA, Scotland

e-mail:jra1@stir.ac.uk

PAULINE MENO

Department of Psychology, University of Stirling 